\title{
«РОКСОЛАНІЯ» СЕБАСТЬЯНА КЛЕНОВИЧА ТА ОСТРОГ
}

\section{Юрій МИНЕНКО}

\author{
старший викладач кафедри української мови і літератури \\ Національного університету «Острозька академія» \\ yurii.mynenko@oa.edu.ua
}

DOI 10.25128/2304-1222.20.51.04

\begin{abstract}
The article deals with the analysis of «Roxolaniia» (1583) by Sebastian Klenovych. When the author descript the towns of Rus he ignore Ostrog - the great center of Ukrainian culture at that time. The Ostrog Academy was founded at1576 and had been operating for 7 years. The scientist V. Shevchuk suggests that the reason for this the absence Latin among the subjects. Modern research proves that Latin was studied at the academy. When the author descript the residents of Lviv he wrote about the Jews negatively, he blamed them in impurity and usury.

There is was a large Jewish community in Ostrog which was formed at the beginning of $16^{\text {th }}$ century. The Great Synagogue and the Talmudic Higher School (Yeshibot) were operated here. Ostog was a main center of Judaism in Volyn. So personal dislike to Jewish nationality was the real reason why Klenovych named less important towns at that time but did not mention Ostrog.
\end{abstract}

Keywords: Latin poetry, Ostroh Academy, synagogue, Talmudic High school, Jewish community.

Стаття присвячена аналізу «Роксоланії» (1584) Себастьяна Кленовича. В описі міст Русі автор ігнорує Острог попри те, що на той час він був великим центром української культури. Уже 7 років діяла Острозька академія, що була заснована 1576 року. Вчений В. Шевчук припускає, що причиною цього $є$ відсутність серед навчальних предметів закладу латинської мови. Сучасні дослідження доводять, що латинську мову в академії вивчали. В описі мешканців Львова Кленович негативно описав євреїв, звинувативши їх у нечистоті і лихварстві.

На початку XVI століття в Острозі сформувалася велика єврейська громада. Тут діяла Велика синагога i вища талмудична школа (єшибот). Саме Острог у цей час став головним центром іудейства Волині. Тож особиста неприязнь до єврейської національності була справжньою причиною, чому Кленович називає менш значимі на той час міста, але не згадує Острог.

Ключові слова: латиномовна поезія, Острозька академія, синагога, вища талмудична школа, єврейська громада.

Artykuł poświęcony jest analizie „Roksolanii” (1583) Sebastiana Klenowicza. W opisie miast Rusi autor pomija Ostrog, mimo że był to wówczas główny ośrodek kultury ukraińskiej. Akademia Ostrogska, założona w 1576 roku, działa już od 7 lat. Naukowiec W. Szewczuk sugeruje, że przyczyną tego jest brak języka łacińskiego wśród badanych instytucji. Współczesne badania dowodzą, że na uczelni studiowano łacinę. W opisie mieszkańców Lwowa Klenowicz negatywnie opisał Żydów, zarzucając im nieczystość i lichwę.

Na początku XVI w. w Ostrogu powstała liczna społeczność żydowska. Działała tu Wielka Synagoga i Wyższa Szkoła Talmudyczna (Yeshibot). To właśnie Ostrog stał się wówczas głównym ośrodkiem judaizmu na Wołyniu. Tak osobista niechęć do narodowości żydowskiej była prawdziwym powodem, dla którego Klenowicz wspomniał wówczas o mniej ważnych miastach, ale nie wspomniał o Ostrogu.

Słowa kluczowe: poezja łacińska, Akademia Ostrogska, synagoga, liceum talmudyczne, gmina żydowska.

Українська латиномовна література XV-XVI століть залишається досі малодослідженою у нашій медієвістиці. Це ж стосується і найвідомішого ренесансного твору «Роксоланія» придворного поета польського короля Себастьяна Кленовича. «Роксоланія» $\epsilon$ 
суто «українською» сторінкою його творчої спадщини. Сучасні польські дослідження оминають цей твір, зосереджуючись насамперед на напольськомовних творах автора [Wiśniewska 2006: 8].

Медієвіст Валерій Шевчук, аналізуючи опис міст у цьому творі автора, звернув увагу на цікаву особливість. «Трохи дивно, що ні слова С. Кленович не каже про Острог ... адже Острог на той час був одним із найвизначніших культурних центрів тогочасної України і саме в час написання „Роксоланіи” там кипіло культурне життя. Причину цього бачимо одну: в Острозі на той час зібралася група вчених та культурних діячів, яка заперечувала латиномовну літературу й осуджувала так званих ,латинників”», тобто тих, котрі орієнтувалися на культурні засади європейського Ренесансу» [Шевчук 2004: 153]. Проте такі висновки дослідника потребують певних коректив.

У латиномовній поемі Симона Пекаліда, придворного поета князя Василя-Костянтина Острозького, «Про Острозьку війну» (1600), згадано тримовну острозьку гімназію. «С. Пекалід не розшифровує, які три мови вивчалися в Острозькій гімназії чи то ліцеї, однак не важко здогадатися, що ними були латинська, грецькат та старослов'янська, чи, можливо, також тогочасна українська (руська) книжна мова» [Острозька академія, 2010, с. 303-304]. Про те, що тут працювали знавці вказаних мов, свідчить і «Азбука» 1578 року [Острозька академія 2010: 303-304].

Водночас Валерій Шевчук аналізує опис народностей, які населяють Русь. Окремо він виділяє позитивну характеристику вірмен:

В місті осіли вірмени, свої залишивщи оселі,

Люди кмітливі вони, талановитий народ

Речі иерковні сюди привезли та своїх ієреїв,

Церкву, як звичай велить, побудували собі [Українська поезія 1987: 150].

Таке приязне ставлення С. Кленовича до цього етносу, а також наслідування його мотивів С. Симонідом і братами Зиморовичами (усі троє - вірмени за походженням, які прийняли католицизм) дає підстави говорити про його вірменське чи змішане українськовірменське коріння [Шевчук 2004: 155]. Це одна з причин, чому, на його думку, автор у поемі говорить про Русь як окреме етнічне тіло, а не складову частину Речі Посполитої.

Загалом у характеристиці населення міста Львова, громаді якого присвячений твір, згадано представників чотирьох груп. Причому показовою, на нашу думку, є не лише характеристика міщан, а й кількість рядків, присвячених їм. Так, монахів-бернардинців описано 10-ма рядками. Вочевидь, для поета вони втілювали ідеал Христового мучеництва i самопожертви, адже оповідь про них завершується рядком:

Муки й наругу страшну терплять та всяку нужду [Українська поезія 1987: 150].

Далі у творі позитивними барвами змальовано вірменську громаду міста, іï опис займає 12 рядків: 
Також сюди вірменин пелехатий завозить зі Сходу

Пахощі різні свої й всякий на продаж товар [там само].

Лише двома рядками згадано українське населення Львова:

Також руси живуть, населення грецької віри,

I за обрядом свойм храми будують святі [там само].

Відверту неприязнь автор висловлює єврейському населенню міста. Вони для Кленовича асоціюються 3 брудом, лихварством, визиском; їхня віра $є$ неправдивою. Тоді, як і до православних вірмен, i до русів, і до членів католицького ордену бернардинців він ставився 3 повагою. Тож наведемо цей фрагмент повністю.

На передмістю бруднім проживають невірні євреї, У неохайних хатках їхніх - $і$ бруд, і сміття.

Плем'я смердюче вони, розвівається, наче від изапа, Сморід постійно від них, завжди обличчя блідi.

Їх синагога реве голосами разюче дзвінкими,

Все там змішалось у ній: галас, молитва і крик.

Зробить із чорного біле народ чей, із правди - неправду,

Прагне, аби із небес падала манна йому.

Що ж поробляє, спитаєш, єврей у славетному місті?

Що виробляє той вовк серед отари овещь?

Славні міста у заставу дає, позичає всім гроші,

3 них же проценти дере, сіє усюди нужду.

Наче той шашіль, щуо точить могутні дуби поступово,

Чи оті черви, щчо вмить все перетворять у гниль,

Мовби тихесенька п'явка, що кров n'є людську невідчутно

Й силу й життєвий запал нишком в людей відбира,

Як ось іржа роз '̈̈дає залізо, а міль одежину,

Так і нероба єврей нищить, руйнує усе.

Безліч приватних маєтків не раз зруйнував хитромудро,

Часто й державне майно нищив ией спритний лихвар.

Розуму вчились, хоч пізно, обдерті євреєм монархи,

Прийде в державу єврей - стогне печально вона.

Стріне державу ие лихо - лежить, наче тіло безкровне,

Крові і сили тоді зовсім у неї нема.

Отже, чумою иією гордуй, моя Таліє мила,

А проклинати - ие гріх! Роде невірний, прощай [там само: 150-151].

Складно сказати, чим зумовлена така непотязнь до цього народу. Можливо, Кленович став жертвою єврея-лихваря чи зазнав якоїсь іншої кривди. Важлива згадка про проживання іудеїв у передмісті, тобто вони не становили значну частину населення. Загалом же, станом на 1583 рік у місті проживало 14 тисяч євреїв [Населення Львова].

Таке ставлення до цього етносу помічаємо і у творах, написаних польською мовою. Аналізуючи образи різних народностей у творчості Кленовича, польська медієвістка зазначає: «в «Роксоланії» портрет Сврея-лихваря зображений через бруд, ревіння пісень у синагозі і підступні діяння» [Wiśniewska 2006: 134]. Цей портрет зустрічається і в наступних творах автора. Прикметно, що датою народження С. Кленовича вона вважає 1545 рік, помер же у віці 57 років 1602 року. Про це ми дізнаємося з інформації історика Речі Посполитої Шимона 
Старовольського, опублікованій у Варшаві у 25-ті роковини смерті поета. Українські ж медієвісти відносять цю подію до 1550 року [Українська поезія 1987: 113].

Для повноти пояснення неприязні Кленовича до Острога, що на той час був визначним центром національної культури і в якому на час написання твору вже 8 років діяла тримовна Острозька академія (іiі заснування відносять до 1576 року), бракує невеликого штриха з історії міста XVI століття.

Євреї з'явилися в Острозі наприкінці XIV століття «Євреї прибували до нас з різних кінців світу ... найбільше приходило їх 3 німецьких земель» [Kardaszewich 2013: 117] Найбільшого розквіту єврейська громада досягла на початку XV ст., коли на запрошення князів Острозьких стали прибувати євреї 3 багатьох країн для розвитку торгівлі i промисловості. Поступово сформувався великий єврейський центр, і євреї аж до Другої світової війни складали більшість населення Острога. Так, скажімо, «За даними магістрату, в 1930 р. в Острозі проживало 12975 осіб. 3 них 57,5\% населення - євреї» [Руй 2016: 7]. Виняток становлять роки національно-визвольної війни під проводом Богдана Хмельницького. «Так 1660 року в Острозі налічувалося лише 5 будинків, що належали євреям» [Острог: Электронная еврейская энциклопедия].

Уже на початку XVI століття при Великій єврейській синагозі (що збереглася до сьогодні і є визначною пам'яткою міста) діяв єшибот (дослівно «збори, нарада учнів під головуванням вченого-равина») - вища талмудична школа. «Крім учнівської молоді, заняття в єшиботі відвідували вчені-євреї як з місцевої, так і з інших громад, що вже здобули талмудичну освіту і бажали поглибити іiі ... » [Острозька академія 2010: 115]. Утримувала школу єврейська громада міста, а учнів єшибота називали «бахурами». Острозька равинська школа відзначалася високом рівнем викладання і підготовки ії випускників.

Про діяльність школи, синагоги і друкарні згадує і відомий історик Острога Станіслав Кардашевич. Вплив і чисельність єврейської громади, що проживала на вулиці Старожидівській у південно-східній частині міста, був настільки значним, що власниця Острога Анна Алоїза-Ходкевич 22 липня 1627 р. своїм указом наказала євреям: «своїх божниць високо над костели і церкви не виносити, в дні значних дат з церемонією не ховати (померлих - Ю.М.)» [Kardaszewich 2013: 119].

Саме в Острозі працювали такі відомі талмудисти, як Соломон Лур'є та Ісай Горович і Самуїл Едельс (Маршуе). Останній тривалий час був ректором єшибота і головним равином Острога. Нині на його честь названа одна з вулиць міста [Манько 2015: 6]. На початку XVII століття головний равин Острога керував духовним життям усіх євреїв Волині. Відомо, що у місті, окрім великої, діяла ще й мала синагога (чи навіть кілька), проте рештки цих споруд не збереглися. Принаймі наприкінці XIX століття в Острозі діяло три синагоги і 19 молитовних будинків [Острог: Электронная еврейская энциклопедия]. 
Загалом час князювання в Острозі Василя-Костянтина Острозького є унікальним прикладом релігійної толерантності. Попри проживання в Острозі різних етнічних і релігійних груп, не сталося жодного протистояння між ними. На той час у місті мешкали греки, татари, українці-русини, аріани, тринітарії й усі ці групи мали свої церковні споруди.

Економічний розквіт острозького єврейства у XVI - першій половині XVII століття й вище згадувана віротерпимість сприяли формуванню відомого у Східній і Центральній Європі осередку єврейської культури. Високий авторитет її представників дав підстави називати місто «Волинським Срусалимом» і тлумачити власну назву міста як «Місто Заповіту», «Місто Тори», (Os-Torach).

Навряд чи вдасться встановити біографічні причини неприязні Себастьяна Кленовича до єврейської національності. Проте тепер у світлі вище наведених фактів стає цілком зрозумілим ігнорування Острога під час опису міст Русі у поемі «Роксоланія», адже Острог на той час був великим центром іудейства.

\section{ЛІТЕРАТУРА}

Манько, М. Їхні імена з'являться на мапі Острога. «Замкова гора». 2015. №34. 6 [Man’ko, М. Yikhni imena zyavlyatsya na mapi Ostroha. „Zamkova hora”. 2015. №34. 6].

Населення Львова. В: Вікіпедія: вільна енциклопедія. URL: http://www.uk.wikipedia.org [Naselennya L'vova. V. Vikipediya: vil'na entsiklopediya].

Острог. Электронная еврейская энциклопедия. URL: eleven.co.il/diaspora/communities/13106. [Ostrog. Elektronnaya yevreyskaya entsiklopediya]

Острозька академія XVI-XVII століття: Енциклопедія, (ред.) I. Пасічник. Острог: Вид. НУ «Острозька академія», 2010 [Ostroz'ka akademiya XVI-XVII stolittya: Entsiklopediya, (ed.) I. Pasichnik. Ostroh: Vid. NU „Ostroz'ka Akademiya”. 2010].

Руй, О. Згадуючи передвоєнний Острог та його населення. «Замкова гора». 2016. №31 (943). 30.07. 7 [Ruy, O. Zhaduyuchi peredvoyenniy Ostroh ta yoho naselennya. „Zamkova hora”. 2016. No 31 (943). 30.07. 7].

Українська поезія XVI ст., упоряд. В.Яременко. Київ: Радянський письменник, 1987 [Ukrayins'ka poeziya XVI st., uporyad. V.Yaremenko. Kiyiv: Radyans'kiy pis'mennik, 1987].

Шевчук, В.О. Муза Роксоланська: Українська література XVI - XVIII століть: у 2 кн. Київ: Либідь, 2004. Кн.1 [Shevchuk, V.O. Muza Roksolans'ka: Ukrayins'ka literatura XVI - XVIII stolit': u 2 kn. Kiyiv: Libid', 2004. Kn. 1].

Kardaszewich, S. Dzieje dawniejsze miasta Ostroga. Biały Dunajec - Ostróg 2013.

Wiśniewska, H. Renesansowe życie i dzieło Sebastiana Fabiana Klonowica. Wydawnictwo UMCS, Lublin 2006. 